\title{
Effects of Nitrogen Input on Community Structure of the Denitrifying Bacteria with Nitrous Oxide Reductase Gene (nosZI): A Long-Term Pond Experiment
}

\section{Jing Zhou}

Qufu Normal University

Yong Kong

Qufu Normal University

\section{Mengmeng Wu}

Shandong Freshwater Fisheries Research Institute

\section{Fengyue Shu}

Qufu Normal University

Haijun Wang ( $\square$ wanghj@ihb.ac.cn )

Yunnan University https://orcid.org/0000-0001-6963-2557

\section{Shuonan Ma}

Institute of Hydrobiology, Chinese Academy of Sciences

\section{Yan Li}

Institute of Hydrobiology, Chinese Academy of Sciences

\section{Erik Jeppesen}

Aarhus University

\section{Research Article}

Keywords: nosZ I, long-term test, nitrogen addition, whole-ecosystem experiment

Posted Date: December 20th, 2021

DOI: https://doi.org/10.21203/rs.3.rs-1145044/v1

License: (c) (1) This work is licensed under a Creative Commons Attribution 4.0 International License. Read Full License

Version of Record: A version of this preprint was published at Microbial Ecology on February 3rd, 2022. See the published version at https://doi.org/10.1007/s00248-022-01971-4. 


\section{Abstract}

Excessive nitrogen $(\mathrm{N})$ input is an important factor influencing aquatic ecosystems and has received increasing public attention in the past decades. It remains unclear, however, how $\mathrm{N}$ input affects the denitrifying bacterial communities that play a key role in regulating $\mathrm{N}$ cycles in various ecosystems. To test our hypothesis - that the abundance and biodiversity of denitrifying bacterial communities decrease with increasing $\mathrm{N}$ - we compared the abundance and composition of denitrifying bacteria having nitrous oxide reductase gene (nos $Z$ I) from sediments $(0-20 \mathrm{~cm})$ in five experimental ponds with different nitrogen fertilization treatment (TN10, TN20, TN30, TN40, TN50) using quantitative PCR and pyrosequencing techniques. We found that: 1) $\mathrm{N}$ addition significantly decreased nos $Z$ I gene abundance, 2) the Invsimpson and Shannon indices (reflecting biodiversity) first increased significantly along with the increasing $\mathrm{N}$ loading in TN10 TN40 followed by a decrease in TN50,3) the beta diversity of the nosZ I denitrifier was clustered into three groups along the TN concentration levels: Cluster I (TN50), Cluster II (TN40), and Cluster III (TN10-TN30), 4) the proportions of Alphaproteobacteria and Betaproteobacteria in the high-N treatment (TN50) were significantly lower than in the lower $\mathrm{N}$ treatments (TN10-TN30). 5). The $\mathrm{TN}$ concentration was the most important factor driving the alteration of denitrifying bacteria assemblages. Our findings shed new light on the response of denitrification-related bacteria to long-term $\mathrm{N}$ loading at pond scale and on the response of denitrifying microorganisms to $\mathrm{N}$ pollution.

\section{Introduction}

Nitrogen $(\mathrm{N})$ is a key element sustaining life and is one of the most abundant elements on earth [1]. In $2050,60 \%$ of global production of $\mathrm{N}$ is expected to come from anthropogenic sources [2] such as industrial fertilizer production, biological fixation of $\mathrm{N}$ in agricultural systems, and combustion. The increases in $\mathrm{N}$ production have resulted in large increases in the fluxes of $\mathrm{N}$ in nature [3]. Unintentional $\mathrm{N}$ enrichment has a variety of negative environmental impacts, including soil acidification [4], reduction of global terrestrial biodiversity [5], increased nutrient runoff to aquatic ecosystems, and eutrophication worldwide [6], and such changes can ultimately impact ecosystem services and human well-being [7].

In aquatic ecosystems, bacteria-mediated denitrification is potentially an important pathway for $\mathrm{N}$ removal by converting nitrate/nitrite into gaseous products $\left(\mathrm{N}_{2}, \mathrm{NO}, \mathrm{N}_{2} \mathrm{O}\right)$ [8]. Mitigation of anthropogenic $\mathrm{N}_{2} \mathrm{O}$ release is not least now in focus as $\mathrm{N}_{2} \mathrm{O}$ is an important greenhouse gas and a major cause of ozone layer depletion [9]. As the only known $\mathrm{N}_{2} \mathrm{O}$ sink, enzymatic reduction to $\mathrm{N}_{2}$, controlled by denitrifiers harboring the nitrous oxide reductase gene (nosZ, consisting of type I and type II) [10], has received increasing attention [11-13]. For example, $\mathrm{N}$ fertilizer has been shown to reduce $\mathrm{N}_{2} \mathrm{O}$ emission from field crops [14], and $\mathrm{N}$ addition increased the denitrification potential in the Broadbalk wheat experiment [15]. It has also been shown that high $\mathrm{N}_{2} \mathrm{O}$ emissions could be attributable to the legacy effect from previous $\mathrm{N}$ addition to cropland or to an interactive effect of $\mathrm{N}$ addition and climate change [16]. However, the change of $\mathrm{N}_{2} \mathrm{O}$-producing bacteria at different nitrogen loadings is unclear. 
$\mathrm{N}$ addition increases the microbial biomass [17], decreases fungal diversity and alter the fungal community composition [18] in the soil. In lake sediments, $\mathrm{N}$ input enhanced the relative abundances of the genera Flavobacterium, Pseudomonas, Arenimonas, Novosphingobium, Massilia, Aquabacterium, and Bacillus but inhibited those of Sporacetigenium, Gaiella, Desulfatiglans, Nitrospira, and Haliangium [12]. As ecological functions tie up closely with microbial communities, the changes of microbial communities inevitably impact functions [19]. Soil studies have revealed that $\mathrm{N}$ addition decreased the population of microbial nitrogen fixers [20], weakened the biological nitrogen fixation capacity [21], and led to loss by denitrification [22, 23]. However, Kramer et al. [24] found that the application of $\mathrm{N}$ in orchards significantly enhanced the activity and efficiency of soil denitrifiers and reduced nitrate leaching. The ultimate effect of $\mathrm{N}$ addition on denitrifiers, however, remains unclear and needs to be elucidated at contrasting $\mathrm{N}$ loadings in different ecosystems.

In this study, the clade I group of nosZ gene was selected to quantify the abundance and communities of denitrifiers, because most microbes with nosZ clade I are complete denitrifiers and play an important role in the $\mathrm{N}_{2} \mathrm{O}$ reduction in aquatic systems [25], while the nos $Z$ clade II is more relevant in soils [26]. In order to investigate the direct influence of $\mathrm{N}$ on the abundance and composition of nos $\mathrm{Z}$ I denitrifying bacteria, we collected sediments $(0-20 \mathrm{~cm})$ from the long-term (4 years) experimental ponds of five nitrogen fertilization treatment (TN10, $10 \mathrm{~kg} \mathrm{NH}_{4} \mathrm{Cl}$ per month; TN20, $20 \mathrm{~kg} \mathrm{NH}_{4} \mathrm{Cl}$ per month; TN30, $30 \mathrm{~kg} \mathrm{NH}_{4} \mathrm{Cl}$ per month; TN40, $40 \mathrm{~kg} \mathrm{NH}_{4} \mathrm{Cl}$ per month; TN50, $50 \mathrm{~kg} \mathrm{NH}_{4} \mathrm{Cl}$ per month) in the north-eastern part of Bao'an lake in Wuhan, China. We hypothesize that (a) high $\mathrm{N}$ concentration will reduce the abundance of denitrifying bacteria, (b) denitrifying bacteria communities will cluster according to the $\mathrm{N}$ gradient, and (c) the differences of nosZ I communities will reflect adaptive shifts by the microbial communities to the $\mathrm{N}$ concentration that they face.

\section{Material And Methods}

\subsection{Experimental design and samples collected}

We performed the experiments in 10 ponds with a depth of $1.8 \pm 0.2 \mathrm{~m}$ (mean \pm standard error) and an area of ca. $0.08 \mathrm{ha}$, located in a warm and humid subtropical climate on the south bank of the middle

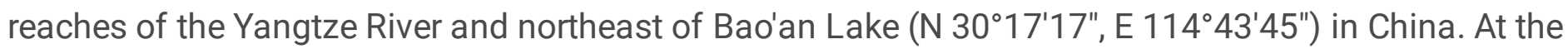
time of the experiment, the ponds had received different loadings of nitrogen for about 4 years (since January 2016). The sediments and water were introduced from Lake Bao'an with the aim to create a natural lake system [27]. The experimental treatments consist of five fertilization treatment, with additions of $\mathrm{NH}_{4} \mathrm{Cl}$ of 10 (TN10), 20 (TN20), 30 (TN30), 40 (TN40), 50 (TN50) kg per month. $\mathrm{NH}_{4} \mathrm{Cl}$ fertilizer $\left(\mathrm{NH}_{4} \mathrm{Cl}, \geq 99.5 \%\right.$, Shanghai Guoyao Chemical Reagent Co., Ltd.) was added to the pond every month as a nitrogen source. Phosphate fertilizer was not added. In October 2019, samples from the upper approx. $20 \mathrm{~cm}$ of the sediment were collected using an in situ sediment gravity sampler (Rigo, $\Phi=0 \mathrm{~cm}$ ). We randomly collected three sediment samples from each pond and added the sediment to sampling tubes (LaMotte, \#1055) that were stored in a portable refrigerator until being transported back to the 
laboratory. We collected a total of 30 sediment samples ( 3 individuals * 2 sample sites * 5 ponds). In the lab, one part of the samples was immediately put in the refrigerator to be stored at $-80^{\circ} \mathrm{C}$ for microbial investigation, while the other part was used for nutrient analyses.

\subsection{Physico-chemical parameters}

Sediment samples were naturally air dried at room temperature and sieved through a 1-mm screen. The following seven physico-chemical parameters were measured: soil $\mathrm{pH}, \mathrm{NO}_{3}{ }^{-}$content, $\mathrm{NH}_{4}{ }^{+}$, total nitrogen (TN), available phosphorus (AP), available potassium (AK), and organic matter (OM) [21]. All sediment properties were measured by the Analysis and Testing Center of the Chinese Academy of Agricultural Sciences (IEDA, CAAS, Beijing, China).

\subsection{DNA extraction and Quantitative PCR (qPCR) analysis}

The Fast DNA SPIN Kit (MP Biomedicals, OH, USA) was used to extract total microbial DNA from the sediment [18]. The standard curve with 10 -fold serial dilution was generated by a plasmid containing a copy of randomly selected nos Z I PCR products with primer nosZ1840-F / nosZ2090-R [28]. The calculated equation was: abundance of gene copy number $/ \mu L=\left(\right.$ amount $\left./ \mu L^{*} 6.022 * 10^{14}\right) /($ length * 324). The qPCR reaction systems were conducted in a volume of $20 \mu \mathrm{L}$, which consisted of $1 \mu \mathrm{L}$ DNA template, $8.4 \mu \mathrm{L}$ sterile and DNA-free water, $10 \mu \mathrm{L}$ premix (2×SG qPCR MasterMix), $0.3 \mu \mathrm{L}$ forward primer $(10 \mu \mathrm{M})$, and reverse primer $(10 \mu \mathrm{M})$. The condition of qPCR was set as $95^{\circ} \mathrm{C}$ for $3 \mathrm{~min}$, followed by 40 cycles of $95^{\circ} \mathrm{C}$ for $10 \mathrm{~s}, 55^{\circ} \mathrm{C}$ for $10 \mathrm{~s}$, and $72^{\circ} \mathrm{C}$ for $20 \mathrm{~s}$. The correlation coef $\square$ cients of standard curves $\left(R^{2}\right)$ were higher than 0.99 . Finally, the absolute abundance of gene copy numbers was calculated and normalized to $1 \mu \mathrm{L}$ DNA.

\subsection{Pyrosequencing, bioinformatics processing, and statistical analysis}

The nosZ I gene was amplified by a touchdown PCR using TransGene high-fidelity enzyme with primer nosZ1840-F / nosZ2090-R [28]. The PCR process was pre denatured at $94^{\circ} \mathrm{C}$ for 5 minutes, annealed at $94^{\circ} \mathrm{C}$ for 30 seconds, annealed at $55^{\circ} \mathrm{C}$ for 35 seconds, and annealed at $72^{\circ} \mathrm{C}$ for 30 seconds, $94^{\circ} \mathrm{C}$ for 30 seconds, 94 seconds. The annealing time is $30 \mathrm{~s}, 55 \sim 51^{\circ} \mathrm{C}$ for $35 \mathrm{~s}, 72^{\circ} \mathrm{C}$ for $30 \mathrm{~s}$, a total of 25 cycles. The amplified PCR products were sequenced on the Illumina miseq Pairend $2 \times 250$ platform, which is located at Beijing Fixgene Co., Ltd. (Beijing, China).

The raw sequences were submitted in the NCBI Sequence Reading Archive (SRA) with the registration number of PRJNA734490. The nucleotide sequences of nosZ I were analyzed with the QIIME-1.9.1 pipeline. In short, low-quality sequences were discarded, and the remaining sequences were converted to amino acid sequences using the FunGene Pipeline of the Ribosomal Database Project [21]. The sequences that did not match the nitrousoxide reductase gene sequence were removed and the remaining high quality sequences were subsampled based on the lowest number of reads in a sample. Operable classification units (OTUs) were classified with a similarity of 95\%. For alpha diversity, Shannon, Chao, and Shannon Even indices were calculated for each sample using the UPARSE pipeline [29]. For beta 
diversity, Bray-Curtis dissimilarities were calculated for the microbiota of all 30 samples using the $\mathrm{R}$ package vegan [21]. The Bray-Curtis dissimilarities were used for principal coordinate analysis (PCoA) and hierarchical clustering [30]. Analysis of variance was performed with a randomized complete block design using one-way analysis of variance (ANOVA) with Tukey's HSD test using IBM SPSS Statistics 21 [31]. We used the term 'Differential genera' to refer to a genus that is found in significantly different proportions among five groups. A phylogenetic tree was inferred of these differential genera using the neighbor joining method in MEGA v.6.1 and displayed using the iTOL (Interactive Tree Of Life, https://itol.embl.de/) together with data on the average relative abundances of genera [21]. The correlations between nosZ I communities (at genus level) and physico-chemical parameters were determined with redundancy analysis (RDA) using CANOCO 5.0.

\section{Results}

\subsection{Physico-chemical characteristics of sediments}

Data on sediment characteristics are provided in Table 1. pH in TN40 and TN50 were significantly lower than in TN20 and TN30. The content of $\mathrm{NH}_{4}{ }^{+}$and TN evidently increased with the increase of $\mathrm{N}$ levels. The content of AK in TN50 was significantly lower than at the other $\mathrm{N}$ levels. The contents of $\mathrm{NO}_{3}{ }^{-}$and AP in TN30 were significantly higher than in the other four treatments. However, the OM content did not differ signi $\square$ cantly among the five groups 
Table 1

Physico-chemical parameters of sediments across the $\mathrm{N}$ gradient

\begin{tabular}{|c|c|c|c|c|c|c|c|}
\hline Treatments $^{1}$ & $\mathrm{pH}$ & $\begin{array}{l}\mathrm{NO}_{3}^{-} \\
(\mathrm{mg} \\
\left.\mathrm{kg}^{-1}\right)\end{array}$ & $\begin{array}{l}\mathrm{NH}_{4}^{+} \\
\left(\mathrm{mg} \mathrm{kg}^{-1}\right)\end{array}$ & $\begin{array}{l}\mathrm{TN}^{2} \\
(\mathrm{~g} \\
\left.\mathrm{kg}^{-1}\right)\end{array}$ & $\begin{array}{l}\mathrm{AP}^{3} \\
(\mathrm{mg} \\
\left.\mathrm{kg}^{-1}\right)\end{array}$ & $\begin{array}{l}\mathrm{AK}^{4} \\
\left(\mathrm{mg} \mathrm{kg}^{-1}\right)\end{array}$ & $\begin{array}{l}\mathrm{OM}^{5} \\
(\%)\end{array}$ \\
\hline TN10 & $\begin{array}{l}7.39 \pm \\
0.11 \mathrm{ab}\end{array}$ & $\begin{array}{l}7.83 \pm \\
1.48 a\end{array}$ & $\begin{array}{l}23.64 \pm \\
0.25 a\end{array}$ & $\begin{array}{l}2.47 \pm \\
0.3 a\end{array}$ & $\begin{array}{l}5.99 \pm \\
0.89 a\end{array}$ & $\begin{array}{l}136.23 \pm \\
10.63 b\end{array}$ & $\begin{array}{l}4.04 \pm \\
0.36 a\end{array}$ \\
\hline TN20 & $\begin{array}{l}7.51 \pm \\
0.11 \mathrm{~b}\end{array}$ & $\begin{array}{l}7.97 \pm \\
0.62 a^{2}\end{array}$ & $\begin{array}{l}27.25 \pm \\
1.35 a\end{array}$ & $\begin{array}{l}2.47 \pm \\
0.2 a\end{array}$ & $\begin{array}{l}4.29 \pm \\
0.66 \mathrm{a}\end{array}$ & $\begin{array}{l}124.59 \pm \\
0.23 a b\end{array}$ & $\begin{array}{l}4.17 \pm \\
0.10 \mathrm{a}\end{array}$ \\
\hline TN30 & $\begin{array}{l}7.59 \pm \\
0.04 \mathrm{~b}\end{array}$ & $\begin{array}{l}12.93 \pm \\
3.11 \mathrm{~b}\end{array}$ & $\begin{array}{l}43.58 \pm \\
4.43 a\end{array}$ & $\begin{array}{l}2.64 \pm \\
0.2 a\end{array}$ & $\begin{array}{l}9.29 \pm \\
1.31 \mathrm{~b}\end{array}$ & $\begin{array}{l}134.57 \pm \\
0.47 \mathrm{~b}\end{array}$ & $\begin{array}{l}3.83 \pm \\
0.08 \mathrm{a}\end{array}$ \\
\hline TN40 & $\begin{array}{l}7.18 \pm \\
0.04 a\end{array}$ & $\begin{array}{l}4.06 \pm \\
1.07 a\end{array}$ & $\begin{array}{l}148.64 \pm \\
24.53 b\end{array}$ & $\begin{array}{l}3.71 \pm \\
0.4 \mathrm{~b}\end{array}$ & $\begin{array}{l}5.26 \pm \\
0.95 a\end{array}$ & $\begin{array}{l}120.46 \pm \\
6.61 \mathrm{ab}\end{array}$ & $\begin{array}{l}4.37 \pm \\
0.34 a\end{array}$ \\
\hline TN50 & $\begin{array}{l}7.18 \pm \\
0.13 a\end{array}$ & $\begin{array}{l}4.56 \pm \\
0.83 a\end{array}$ & $\begin{array}{l}464.32 \pm \\
71.28 \mathrm{c}\end{array}$ & $\begin{array}{l}4.38 \pm \\
0.3 c\end{array}$ & $\begin{array}{l}4.63 \pm \\
0.39 a\end{array}$ & $\begin{array}{l}117.39 \pm \\
5.67 a\end{array}$ & $\begin{array}{l}3.95 \pm \\
0.19 a\end{array}$ \\
\hline
\end{tabular}

Values are mean \pm standard deviation $(n=3)$. Values within the same column followed by letters indicate significant differences $(P<0.05)$.

1 TN0.5 (0.5 mg L-1), TN2 $\left(2 \mathrm{mg} \mathrm{L}^{-1}\right)$, TN10 $\left(10 \mathrm{mg} \mathrm{L}^{-1}\right)$, TN20 $\left(20 \mathrm{mg} \mathrm{L}^{-1}\right)$, and TN100 $\left(100 \mathrm{mg} \mathrm{L}^{-1}\right)$.

${ }^{2} \mathrm{TN}$ : Total nitrogen, ${ }^{3} \mathrm{AP}$ : Available phosphorus, ${ }^{4} \mathrm{AK}$ : Available potassium, ${ }^{5} \mathrm{OM}$ : Organic matter.

\section{2 nosZ I gene abundance}

The numbers of nosZ gene in $1 \mu \mathrm{L}$ DNA ranged from $0.4 \times 10^{4}$ to $1.13 \times 10^{5}$ (Fig. 1 ). There were signi $\square$ cant differences $(P<0.05)$ among the five groups. TN20 and TN30 ponds had higher nosZ gene copy numbers compared to those of TN10, TN30, and TN50. The nosZ gene copy numbers were positively correlated (Pearson's rank correlation, Table 2) with sediment $\mathrm{pH}(\mathrm{R}=0.627, P<0.05)$ and negatively correlated with TN $(\mathrm{R}=-0.550, P<0.05)$.

\subsection{Alpha- and Beta- diversity}

The Invsimpson and Shannon indices in T10 T40 increased gradually and significantly with increasing $\mathrm{N}$ loading but decreased again in T50 ( $P<0.05$, Figure $2 \mathrm{CD})$. There was no obvious difference among the five treatments in the richness indices (ACE and Chao) $(P>0.05$, Figure 2AB). Correlation analysis showed that Ace was positively correlated with TN (Table $2, \mathrm{R}=0.92, P<0.05)$ and AK negatively with Ace $(\mathrm{R}=0.98$, $P<0.01)$ and Chao $(\mathrm{R}=0.96, P<0.05)$.

Principal coordinate analysis showed a close correlation between TN and the nosZ I denitrifier communities (Fig. 3A). The community structures in TN30 were similar to those in TN10 and TN20, while in TN40 it differed significantly from that of the first three groups, and TN50 was separated significantly 
from the other four groups. Along the PC1 axis, the nosZ bacterial communities in TN50 were separated from the other four groups.

The results from the hierarchical clustering analyses were consistent with those of the PCoA analyses. The nos $Z$ I communities in TN50 (Cluster I) were separated from the other four groups. In the remaining four groups, most samples of TN10 and TN20 (8 out of 12 samples, Cluster II) were not in the same branch as TN30 and TN40 (Cluster III) (Fig. 3B).

\subsection{Taxa composition}

The sequencing results (raw data and high-quality reads) are shown in Table S1. A total of 3912958 raw data and 3652792 clean sequences were obtained from the 30 sediment samples, with an average of 121759 sequences per sample (Table S1). The coverage ranged from 98.5-99\%, indicating that the depth of this sequencing is sufficient to reflect the denitrifying microorganisms in the samples (Table S1). A large number of the nos $Z$ gene sequences were affiliated with Proteobacteria, accounting for $95.6-98.3 \%$ of the denitrifying bacteria in the sediment samples, followed by Terrabacteria $(0.12-0.27 \%)$.

At class level, the four dominant classes showed different trends in the different treatments. The proportions of Alphaproteobacteria in TN30 and TN50 were lower than in TN10, TN20, and TN30 (Fig. 4A). Similarly, the class Betaproteobacteria in TN50 was significantly lower than in the other four groups (Fig. 4B). A different pattern was found for Gammaproteobacteria that showed a significantly higher value in TN50 than in the other four groups (Fig. 4C). There was no significant difference in the proportion of Deltaproteobacteria among the five groups (Fig. 5D).

At order level, the proportions of Rhizobiales (Fig. 5A) and Nevskiales (Fig. 5B) in the high TN groups were significantly lower than in the low TN content treatments, while the trend was opposite for the orders Pseudomonadales, Alteromonadales, Rhodospirillales, and Oceanospirillales (Fig. 5E, F, G, H, respectively). The proportions of Nitrosomonadales (Fig. 5C) and Neisseriales (Fig. 5D) increased until TN30 and TN40, followed by a decrease in TN50.

In total, 26 genera differed significantly among the five groups, and they all belonged to the classes Alphaproteobacteria, Betaproteobacteria, or Gammaproteobacteria (Fig. 6 and Table S2). For the most dominant genus Alcanivorax, the proportion increased significantly with increasing TN loading, and the proportion of TN50 increased to $48.6 \%$, being 416 times higher than that of TN10. Pseudomonas, Marinobacter, and Rhodospirillum showed the same trend. However, the relative abundances of Mesorhizobium, Ralstonia, and Massilia decreased with the increase of TN (marked with orange shading in Table S2). The proportion of the 14 genera (marked with gray shading in Table S2) first increased and then decreased significantly with the increase of TN.

\subsection{Redundancy analysis}

In the RDA, physico-chemical parameters explained $29.6 \%$ of changes in nosZ I communities. Axis 1 explained $22.0 \%$, while axis2 explained $7.6 \%$ of the changes (Fig. 7). Total $N(F=6.2, P=0.002)$, Avail $P$ 
( $\mathrm{F}=2.8, P=0.002), \mathrm{NO}_{3}{ }^{-}(\mathrm{F}=2.3, P=0.004), \mathrm{NH}_{4}{ }^{+}(\mathrm{F}=2.0, P=0.01)$, and Avail $\mathrm{K}(\mathrm{F}=1.8, P=0.022)$ (Table S3) were significant factors affecting the nosZ I communities, explaining $41.2 \%$ of the total variation.

\section{Discussion}

We found that $\mathrm{N}$ addition in the ponds had a marked effect on the community and abundance of denitrifying bacteria, as assessed by marker gene analysis of sediment samples collected about 7 years after the initiation of the experimental treatments with contrasting $\mathrm{N}$ loadings (in the interval $10-50 \mathrm{~kg}$ $\mathrm{NH}_{4} \mathrm{Cl}$ per month) of the ponds.

\subsection{Response of physico-chemical properties and nosZ gene abundance of sediment to $\mathbf{N}$ input}

Several studies have shown that the addition of $\mathrm{N}$ can change soil acidity due to the consumption or generation of $\mathrm{H}^{+}[21,32,33]$; for example, $\mathrm{NO}_{3}{ }^{-}$-based fertilizer can increase soil $\mathrm{pH}$ due to the consumption of $\mathrm{H}^{+}$[34]. We found that $\mathrm{N}$ addition decreased sediment $\mathrm{pH}$ (Table 1), reflecting that we used a $\mathrm{NH}_{4}{ }^{+}$-based fertilizer. With the increase of $\mathrm{NH}_{4}{ }^{+}$addition, the $\mathrm{NO}_{3}{ }^{-}$content in the sediment increased and peaked in TN30, followed by a sharp decrease (TN40 and TN50) (Table 1), likely reflecting that low doses of $\mathrm{NH}_{4}{ }^{+}$(TN10 and TN20) promote the metabolic activity of nitrifying bacteria and increase the yield of $\mathrm{NO}_{3}{ }^{-}$, but when $\mathrm{NH}_{4}{ }^{+}$continues to increase, a shift occurs to inhibition of the metabolic activity and abundance of these bacteria. The high number of nosZ I genes in TN20 and TN30 and the lower copy number in TN40 and TN50 concur with this view. However, whether the nosZ I gene copies were transcribed into a corresponding active enzyme that can catalyze $\mathrm{NH}_{4}{ }^{+}$to produce $\mathrm{NO}_{3}{ }^{-}$ remains to be verified by subsequent macrotranscriptomics.

We found that the decrease of $\mathrm{pH}$, caused by $\mathrm{N}$ addition, was significantly positively correlated with the copy number of nosZ I gene, which is consistent with the results of previous studies on the copy number of bacteria [35], fungi [17], ammonia oxidizing prokaryotes [36], and $\mathrm{N}$ fixing bacteria [21] in soil. Harter et al. [37] also found that high $\mathrm{pH}$ (8.4) induced a reduction of $\mathrm{N}_{2} \mathrm{O}$ emissions and influenced the gene expression by regulating the $\mathrm{N}_{2} \mathrm{O}$ enhancement from soil. However, denitrifier-carrying nirk genes become more abundant with increasing $\mathrm{N}$ in soils, while denitrifier-carrying nirS may be at an advantage at low $\mathrm{N}$ [14].

Friedl et al. [38] found that an increase in $\mathrm{NO}_{3}{ }^{-}$availability due to fertilization promoted the reduction of $\mathrm{NO}_{3}{ }^{-}$and suppressed nosZ I abundance in agricultural soils, while we found that there was a significant negative correlation between $\mathrm{TN}$ (not $\mathrm{NO}_{3}{ }^{-}$) and nosZ abundance. These findings suggest that the suppression of the $\mathrm{N}_{2} \mathrm{O}$ reductase and increased $\mathrm{N}$ substrate availability may cause large pulses of $\mathrm{N}_{2} \mathrm{O}$ from the sediments as observed after $\mathrm{N}$ addition to soils [39]. 


\subsection{Response of alpha and beta diversity to $\mathrm{N}$ input}

The Invsimpson index showed similar trend as the Shannon index; thus, it increased with N from TN10 to TN40 but decreased again in TN50. N addition may thus be a key factor controlling the biodiversity and heterogeneity of denitrifier, as also found in a study of denitrification across a N gradient in a western U.S. watershed [39]. The beta diversity of nosZ I denitrifier was strongly influenced by $\mathrm{N}$ and clustered according to the concentration of $\mathrm{N}$, as also seen for other microorganisms related to $\mathrm{N}$ cycling, including ammonia-oxidizing archaea [40] and $\mathrm{N}$-fixing bacteria [21] in black soil using experimental plots.

We found that the changes of some denitrifying groups exhibited a certain regularity with increasing $\mathrm{N}$ at both class, order, and genus level. Rhizobiales, which are known to dominate the denitri 1 cation process in wastewater treatment systems [41], soils [42], and lake sediments [43], have been shown to be significantly influenced by elevated $\mathrm{CO}_{2}$ [42] in wheat roots, and isolates of this groups carry the nosZ gene in their genome and are able to affect $\mathrm{N}_{2} \mathrm{O}$ emissions during wheat growth [44]. In these studies, $\mathrm{N}$ had a pronounced effect on the structure of the $\mathrm{N}_{2} \mathrm{O}$-reducing bacterial community. In the present study, Rhizobiales sharply decreased between TN30 and TN40 and remained low at TN50 (Fig. 4A), which is consistent with findings by Ling et al. [45] in soil. The genus Mesorhizobium, belonging to the order Rhizobiales, is reported to be able to denitrify under both aerobic and anaerobic conditions [46], and it was also significantly negatively affected by increasing N (Fig. 5). Bradyrhizobium (in the order Rhizobiales), which is known to be a major contributor to denitrification [47], reached the highest proportion in TN30 but then decreased markedly in TN40 and TN50 (Fig. 6), which corresponds well with changes of $\mathrm{NO}_{3}{ }^{-}$in sediments. Wang et al. [48] also reported the proportion of Bradyrhizobium to be positively correlated with sediment $\mathrm{NO}_{3}{ }^{-}$in a eutrophic lake. Thus, we propose that Bradyrhizobium (containing nosZ I gene) may use substantial amounts of available $\mathrm{N}$ to support their growth, whereas denitrification and denitrifiers will become increasingly less important when $\mathrm{NO}_{3}{ }^{-}$is low. Accordingly, the decreased $\mathrm{NO}_{3}{ }^{-}$in TN40 and TN50 might have restricted the growth of Bradyrhizobium, leading to increasing TN concentrations in the sediments [48].

Rhodospirillales, Pseudomonadales, Alteromonadales, and Oceanospirillales were more abundant in the high-N environment (Fig. 4E-H). The proportions of the genera Rhodospirillum (in the order Rhodospirillales), Marinobacter (in the order Alteromonadales), Alcanivorax (in the order Oceanospirillales), and Pseudomonas (in the order Pseudomonadales) were 34, 2, 416, and 32 times higher at the highest $\mathrm{N}$ loading than at the lowest loading (Fig. 5 and Table S2), respectively. Species belonging to the genus Marinobacter can perform reduction of nitrate to $\mathrm{N}_{2}$ by respiratory processes in anaerobiosis [49]. Species belonging to the genus Alcanivorax were isolated from organically enriched marine sediments and dominated in the bacterial consortium responsible for $\mathrm{N}$ removal [50]. The genus Pseudomonas has been reported as capable of reducing nitrate and nitrite, and the species $P$. stutzeri is a strong denitrifier and possesses the entire complement of denitrifying enzymes [47]. Thus, the significant increase in the proportion of Marinobacter Alcanivorax, and Pseudomonas in the high-N treatment indicates an enhanced ability of eliminating nitrate or nitrite in the high-N treatment environment. 


\section{Conclusions}

In conclusion, the physico-chemical characteristics, nosZ I gene abundance, and the composition of denitrifying bacterial communities of sediments in the experimental ponds in Bao'an lake were clearly affected after 7 years of $\mathrm{N}$ application. The microbial community data presented support the idea that high concentrations of $\mathrm{N}$ application have negative effects on denitrifying bacteria in lake sediments, expressed as low diversity and abundance, which may diminish the denitrification capacity of $\mathrm{N}_{2} \mathrm{O}$ reduction to $\mathrm{N}_{2}$ in lake sediments. The community structure of nosZ I denitrifiers was closely negatively related with the level of $\mathrm{N}$ addition as well. However, we only conducted research at the DNA level, and future research is needed to determine the impact of $\mathrm{N}$ on the functional diversity of denitrifiers based on mRNA profiling of nosZ I gene. Further progress is essential for developing a predictive understanding of $\mathrm{N}_{2} \mathrm{O}$ fluxes and generating improved management strategies that can curb $\mathrm{N}_{2} \mathrm{O}$ emissions.

\section{Declarations}

\section{Acknowledgments}

This research benefitted from financial support from the National Natural Science Foundation of China (No. 41807053), the Young Talents Invitation Program of Shandong Provincial Colleges and Universities (No. 2019-6-1), the Strategic Priority Research Program of the Chinese Academy of Sciences (XDB31000000), and the Yunnan Provincial Department of Science and Technology (202103AC100001; 202001BB050078). HJW was supported by the Youth Innovation Association of the Chinese Academy of Sciences as an excellent member (Y201859). EJ was supported by the Tübitak Outstanding Researchers Program, BIDEB 2232 (118C250).

Conflict of interest We declare we have no competing interests.

\section{Author contribution statement}

Jing Zhou: Formal analysis, Investigation, Data curation, Writing- original draft, Visualization. Yong Kong: Methodology, Resources, Writing - review \& editing. Haijun Wang: Conceptualization, Writing review \& editing, Supervision, Project administration, Funding acquisition. Fengyue Shu: Formal analysis. Lan Li and Shuonan Ma: Investigation. Mengmeng Wu: Methodology, Writing - review \& editing. Erik Jeppesen: Resources, Writing - review \& editing.

Ethics approval Not applicable.

\section{Availability of Data and Materials}

The nosZ I gene sequence data from the present study have been archived at the NCBI Sequence Read Archive (SRA) under the BioProject accession number PRJNA734490. 
All authors approve the manuscript, its content, and its submission to Microbial Ecology.

\section{References}

1. Martínez-Espinosa C, Sauvage S, Bitar AA, Green P, Sánchez-Pérez J. (2020) Denitrification in wetlands: A review towards a quantification at global scale. Sci Total Environ 754, 142398.

2. Kanakidou M, Myriokfalitakis SD, Fanourgakis G. (2016) Past, present and future atmospheric nitrogen deposition. J Atmos Sci 73(5): 2039-2047.

3. Stevens CJ, David TI, Storkey J. (2018) Atmospheric nitrogen deposition in terrestrial ecosystems: Its impact on plant communities and consequences across trophic levels. Funct Ecol 32, 1757-1769.

4. Clark CM, Bell M, Boyd JW, Compton JE, Davidson EA, Davis C, Blett T. (2017) Nitrogen-induced terrestrial eutrophication: cascading effects and impacts on ecosystem services. Ecosphere 8, e01877.

5. Lin B, Kumon Y, Inoue K, Tobari N, Xue M, Tsunemi K, Terada A. (2021) Increased nitrogen deposition contributes to plant biodiversity loss in Japan: Insights from long-term historical monitoring data. Environ Pollut 290, 118033.

6. Han B, Mo L, Fang Y, Di H, Wang J, Shen J, Zhang L. (2021) Rates and microbial communities of denitrification and anammox across coastal tidal flat lands and inland paddy soils in East China. Appl Soil Ecol 157, 103768.

7. Jones, L., Stevens, C., Rowe, E.C., Payne, R., Dale, S. 2016. Can on-site management mitigate nitrogen deposition impacts in non-wooded habitats? Biol. Con. 212, 464-475.

8. Larned S, Schallenberg M. (2006) Constraints on phytoplankton production in Lake Ellesmere/Te Waihora. Environ. Cant Rep U06/38.

9. Hein S, Samantha W, Simon O. (2017) Clade II nitrous oxide respiration of Wolinella succinogenes depends on the nosG, $-\mathrm{C} 1,-\mathrm{C} 2$, - $\mathrm{H}$ electron transport module, nosB and a Rieske/cytochrome complex. Environ Microbiol 19, 4913-4925

10. Ai C, Zhang M, Sun Y, Zhang L, Zeng L, Liu Y, Wang X, ChaiY, He P, Liang G, Zhou W. (2020). Wheat rhizodeposition stimulates soil nitrous oxide emission and denitrifiers harboring the nosZ clade I gene. Soil Biol Biochem 143, 107738.

11. Wang F, Chen S, Wang Y, Zhang Y, Hu C, Liu B. (2018) Long-term nitrogen fertilization elevates the activity and abundance of nitrifying and denitrifying microbial communities in an Upland Soil: Implications for nitrogen loss from intensive agricultural systems. Front Microbiol 9, 2424.

12. Li Y, Sun Y, Zhang H, Wang L, Zhang W, Niu L, Wang P, Wang C. (2019) The responses of bacterial community and $\mathrm{N}_{2} \mathrm{O}$ emission to nitrogen input in lake sediment: Estrogen as a co-pollutant. Environ Res $179,108769$.

13. Hu X, Liu J, Wei D, Zhu P, Cui X, Zhou B, Chen X, Jin J, Liu X, Wang G. (2020) Chronic effects of different fertilization regimes on nirS-type denitrifier communities across the black soil region of Northeast China. Pedosphere, 30, 73-86. 
14. Millar N, Doll JE, Robertson, G.P. 2014. Management of nitrogen fertilizer to reduce nitrous oxide (N2O) emissions from field crops. Climate change and agriculture fact sheet series, MSU Extension Bulletin E3152.

15. Clark IM, Buchkina N, Jhurreea D, Goulding K, Hirsch PR (2012) Impacts of nitrogen application rates on the activity and diversity of denitrifying bacteria in the Broadbalk wheat experiment. Philosophical Transactions of the Royal Society of London, 367, 1235-1244.

16. Xu R, Tian H, Pan S, Prior SA, Feng Y, Dangal SR. (2020) Global $\mathrm{N}_{2} \mathrm{O}$ emissions from cropland driven by nitrogen addition and environmental factors: comparison and uncertainty analysis. Global Biogeochem Cy 34.

17. Zhou Z, Wang C, Zheng M, Jiang L, Luo Y. (2017) Patterns and mechanisms of responses by soil microbial communities to nitrogen addition. Soil Biol Biochem 115, 433-441.

18. Zhou J, Jiang X, Zhou B, Zhao B, Ma M, Guan D, Li J, Chen S, Cao F, Shen D, Qin J. (2016b) Thirty four years of nitrogen fertilization decreases fungal diversity and alters fungal community composition in black soil in northeast China. Soil Biol Biochem 95:135-143.

19. Liu M, Zhang W, Wang X, Wang F, Sun R. (2020) Nitrogen leaching greatly impacts bacterial community and denitrifiers abundance in subsoil under long-term fertilization. Agric Ecosyst Environ 294, 106885.

20. Wang D, Sun R, Guo X, Wang D, Chu H. (2015) Effects of long-term application of chemical and organic fertilizers on the abundance of microbial communities involved in the nitrogen cycle. Appl Soil Ecol 95: 171-178.

21. Zhou J, Ma M, Guan D, Jiang X, Zhang N, Shu F, Kong Y, Li J. (2021) Nitrogen has a greater influence than phosphorus on the diazotrophic community in two successive crop seasons in Northeast China. Sci Rep 11(1).

22. Ryden J. (1983) Denitrification loss from a grassland soil in the field receiving different rates of nitrogen as ammonium nitrate. J Soil Sci 34, 355-365.

23. Meng X, Li Y, Yao H, Wang J, Dai F, Wu Y, Chapman S. (2020) Nitrification and urease inhibitors improve rice nitrogen uptake and prevent denitrification in alkaline paddy soil. Appl Soil Ecol 154, 103665.

24. Kramer P, Reganold J, Glover J, Bohannan B, Mooney H. (2006) Reduced nitrate leaching and enhanced denitrifier activity and efficiency in organically fertilized soils. PNAS 103 (12): 4522-4527.

25. Hallin S, Philippot L, Löffler FE, Sanford RA, Jones C.M. (2018) Genomics and ecology of novel $\mathrm{N}_{2} \mathrm{O}$ Reducing microorganisms. Trends Microbiol 26, 43-55.

26. Graf D, Jones CM. Hallin, S. (2014) Intergenomic comparisons highlight modularity of the denitrification pathway and underpin the importance of community structure for $\mathrm{N}_{2} \mathrm{O}$ Emissions. Plos One, 9(12): e114118.

27. Yu Q, Wang HZ, Li Y, Shao JC, Liang XM, Jeppesen E, Wang H. (2015) Effects of high nitrogen concentrations on the growth of submersed macrophytes at moderate phosphorus concentrations. 
Water Res 83, 385-395.

28. Henry S, Bru D, Stres B, Hallet S., Philippot L. (2006) Quantitative detection of the nosZ gene, encoding nitrous oxide reductase, and comparison of the abundances of $16 \mathrm{~S}$ rRNA, narG, nirk, and nosZ genes in soils. Appl Environ Microbiol 72, 5181-5189.

29. [30]Edgar R.C. (2013) UPARSE: highly accurate OTU sequences from microbial amplicon reads. Nat. Methods, 10, 996.

30. Zhou J, Fong JJ. (2021) Strong agricultural management effects on soil microbial community in a non-experimental agroecosystem. Appl Soil Ecol 165, 103970.

31. Wei G, Li M, Shi W, Tian R, Gao Z. (2020) Similar drivers but different effects lead to distinct ecological patterns of soil bacterial and archaeal communities. Soil Biol Biochem 144, 107759.

32. Guo JH, Liu XJ, Zhang Y, Shen JL, Han WX, Zhang W, Christiek P, Goulding K, Vitousek P, Zhang F. (2010) Significant acidification in major Chinese croplands. Science 327, 1008-1010.

33. [34]Luo L, Meng H, Wu RN, Gu J.D. (2017) Impact of nitrogen pollution/deposition on extracellular enzyme activity, microbial abundance and carbon storage in coastal mangrove sediment. Chemosphere. 177, 275-283.

34. Smiley RW, Cook RJ. (1973) Relationship between take-all of wheat and rhizosphere pH in soils fertilized with ammonium vs. nitrate-nitrogen. Phytopathology 63, 882-890.

35. Zhou J, Guan D, Zhou B, Zhao B, Ma M, Qin J, Jiang X, Chen S, Cao F, Shen D, Li J. (2015) Influence of 34-years of fertilization on bacterial communities in an intensively cultivated black soil in northeast China. Soil Biol Biochem 90, 42-51.

36. Rippel T, Chapman SK. (2020) Comparing the impacts of an invasive grass on nitrogen cycling and ammonia-oxidizing prokaryotes in high-nitrogen forests, open fields, and wetlands. Plant Soil, 1-13.

37. Harter J, Krause H, M, Schuettler S, Ruser R, Fromme M, Scholten T, Kapple,A, Behrens S. (2014) Linking $\mathrm{N}_{2} \mathrm{O}$ emissions from biochar-amended soil to the structure and function of the $\mathrm{N}$-cycling microbial community. ISME J 8, 660-674

38. Friedl J, Scheer C, Rowlings DW, Deltedesco E, Keiblinger K.M. (2020)Effect of the nitrification inhibitor 3,4-dimethylpyrazole phosphate (DMPP) on $\mathrm{N}$-turnover, the $\mathrm{N}_{2} \mathrm{O}$ reductase-gene nosZ and $\mathrm{N}_{2} \mathrm{O}: \mathrm{N}_{2}$ partitioning from agricultural soils. Sci Rep 10(1).

39. Eberhard EK, Marcarelli AM, Baxter CV. (2018) Co-occurrence of in-stream nitrogen fixation and denitrification across a nitrogen gradient in a western U.S. watershed. Biogeochemistry, 139(2):179195.

40. Zhou J, Jiang X, Zhou B, Ma M, Guan D, Li J. (2016a). Effects of long term application of urea on Ammonia oxidizing archaea community in black soil in Northeast China. Scientia Agricultura Sinica (in Chinese) 49, 294-304.

41. Zhang Y, Wang L, Han W, Wang X, Guo Z, Peng F, Yang F, Kong M, GaoY, Chao J,Wu D, Xu B, Zhu Y. (2017) Nitrate removal, spatiotemporal communities of denitrifiers and the importance of their genetic potential for denitrification in novel denitrifying bioreactors. Bioresour Technol 241, 552-562. 
42. Usyskin-Tonne A, Hadar Y, Yermiyahu U, Minz D. (2020) Elevated $\mathrm{CO}_{2}$ has a significant impact on denitrifying bacterial community in wheat roots. Soil Biol Biochem 142, 107697.

43. Podlesnaya G, Potapov S, Krasnopeev A, Shtykova Y. Belykh O. (2020) Diversity of denitrifying bacteria in biofilms formed on stony substrates of the lake Baikal Littoral Zone. Microbiology 89, 369-373.

44. Usyskin-Tonne A, Hadar Y, Minz D. (2019) Altering $\mathrm{N}_{2} \mathrm{O}$ emissions by manipulating wheat root bacterial community. Sci Rep 9, 7613.

45. Ling N, Chen D, Guo H, Wei J, Bai Y, Shen Q, Hu, S. (2017) Differential responses of soil bacterial communities to long-term $N$ and $P$ inputs in a semi-arid steppe. Geodema 292, 25-33.

46. Song K, Suenaga T, Hamamoto A, Satou K, Riya S, Hosomi M, Terada A. (2014) Abundance, transcription levels and phylogeny of bacteria capable of nitrous oxide reduction in a municipal wastewater treatment plant. J Biosci Bioeng 118, 289-297.

47. [48]Zou $Y$, Lin M, Xiong W, Wang $M$, Zhang J, Wang M, Sun Y. (2018) Metagenomic insights into the effect of oxytetracycline on microbial structures, functions and functional genes in sediment denitrification. Ecotoxicol Environ Saf 161, 85-91.

48. Wang C, Gao H, Chen J, Wang P, Zhang J, Hu Y, Pan Y. (2021) Long-term effects of decabromodiphenyl ether on denitrification in eutrophic lake sediments: Different sensitivity of sixtype denitrifying bacteria. Sci. Total Environ. 774, 145147.

49. Bonin P, Vieira C, Grimaud R, Militon C, Michotey V (2015) Substrates specialization in lipid compounds and hydrocarbons of Marinobacter genus. Environ. Sci Pollut Res 22, 15347-15359.

50. Kalniņš M, Bērziņš A, Gudrā D, Megnis K, Fridmanis D, Danilko P, Muter O. 2020. Selective enrichment of heterotrophic nitrifiers Alcaligenaceae and Alcanivorax spp. from industrial wastewaters. AIMS Microbiol. 6(1):32-42.

\section{Figures}




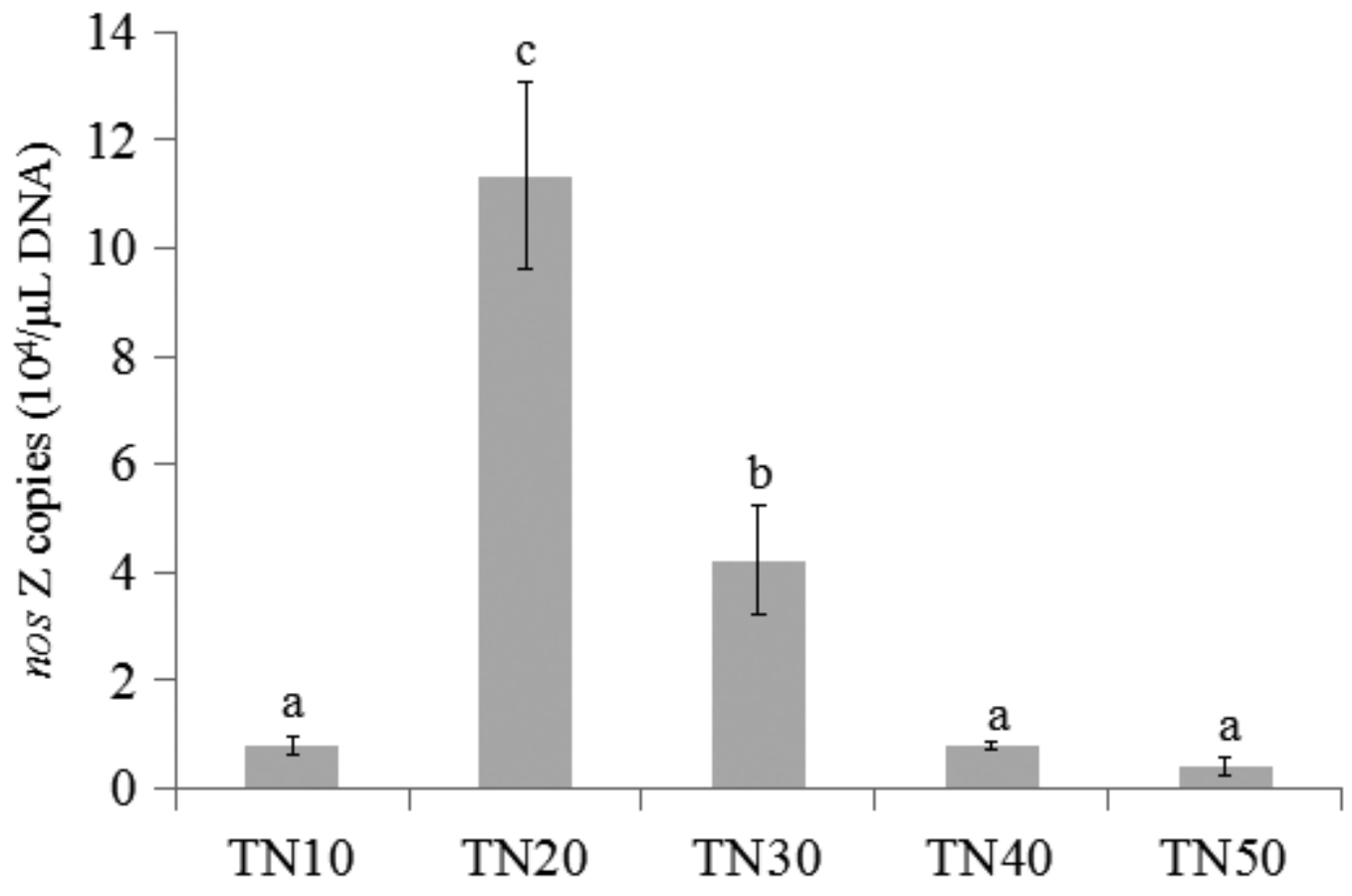

Figure 1

nosZ gene copy numbers in the five treatment groups based on qPCR. 

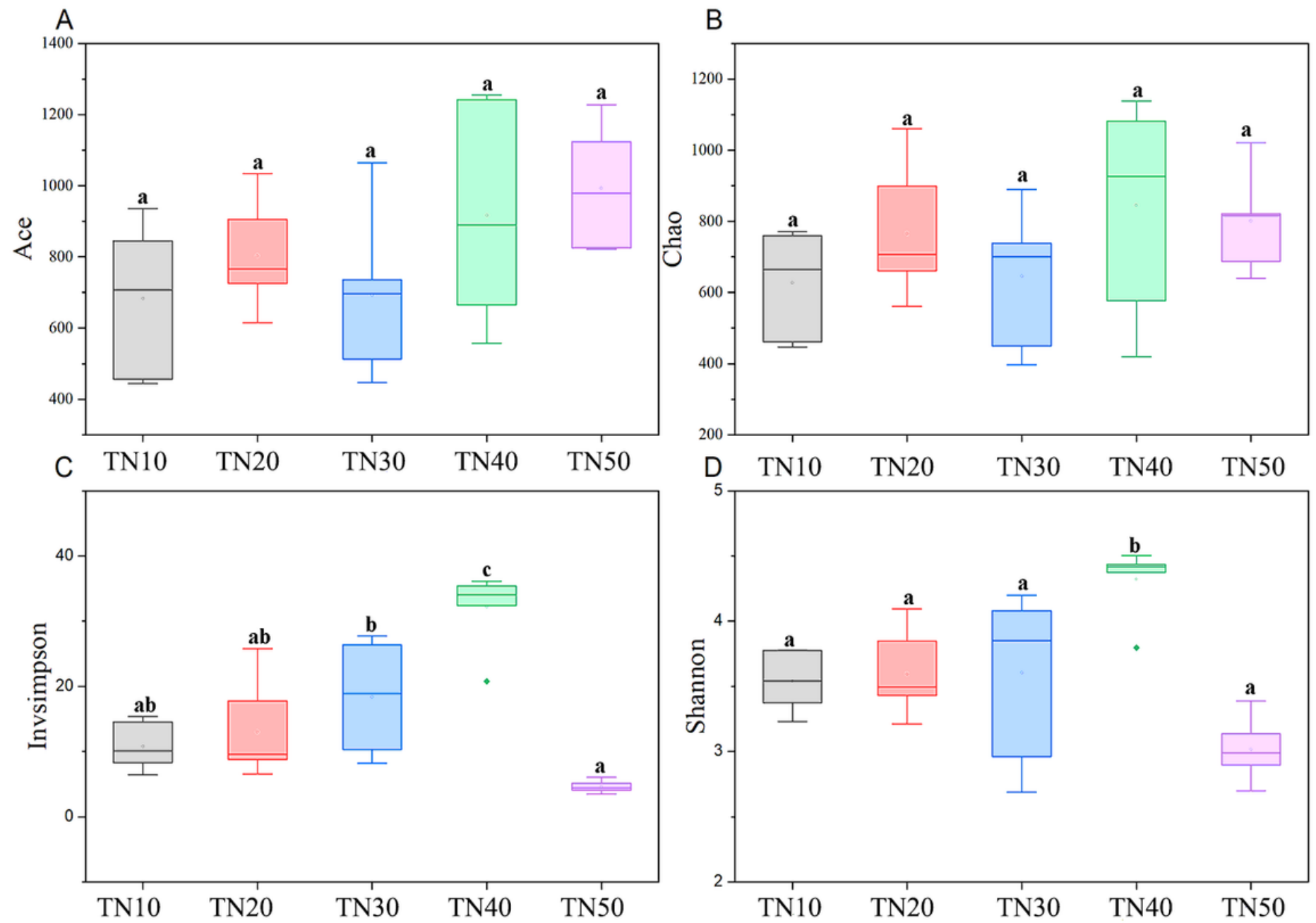

Figure 2

Alpha diversity indices along the $\mathrm{N}$ gradient. 
A

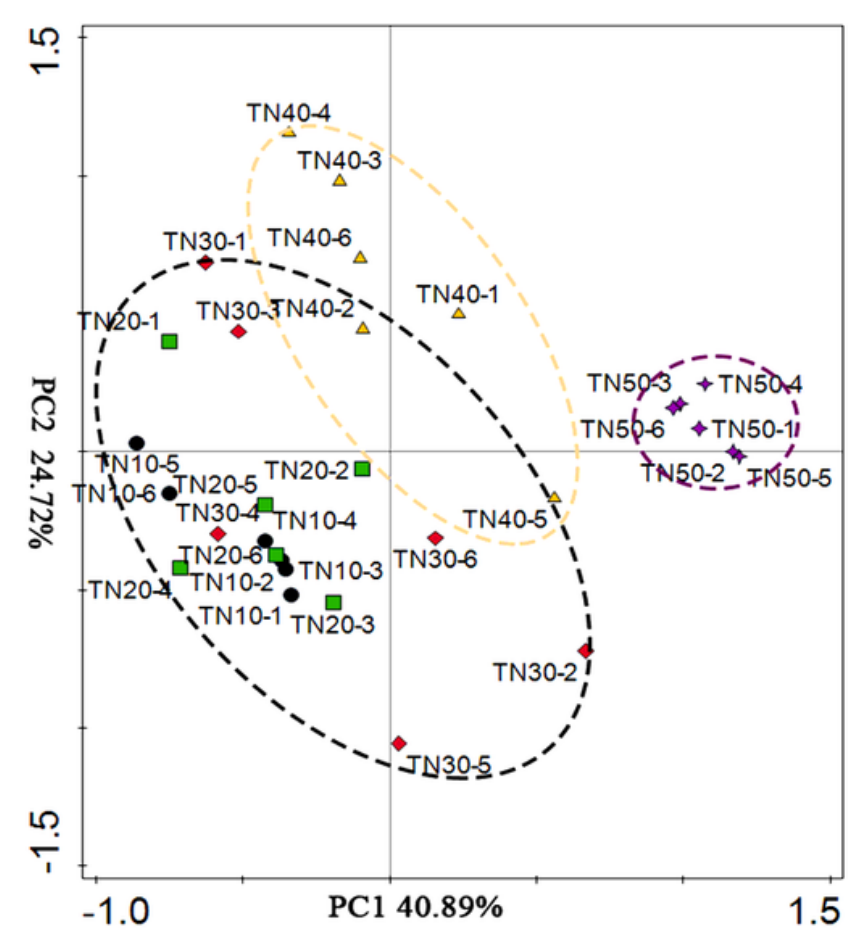

$\mathrm{B}$

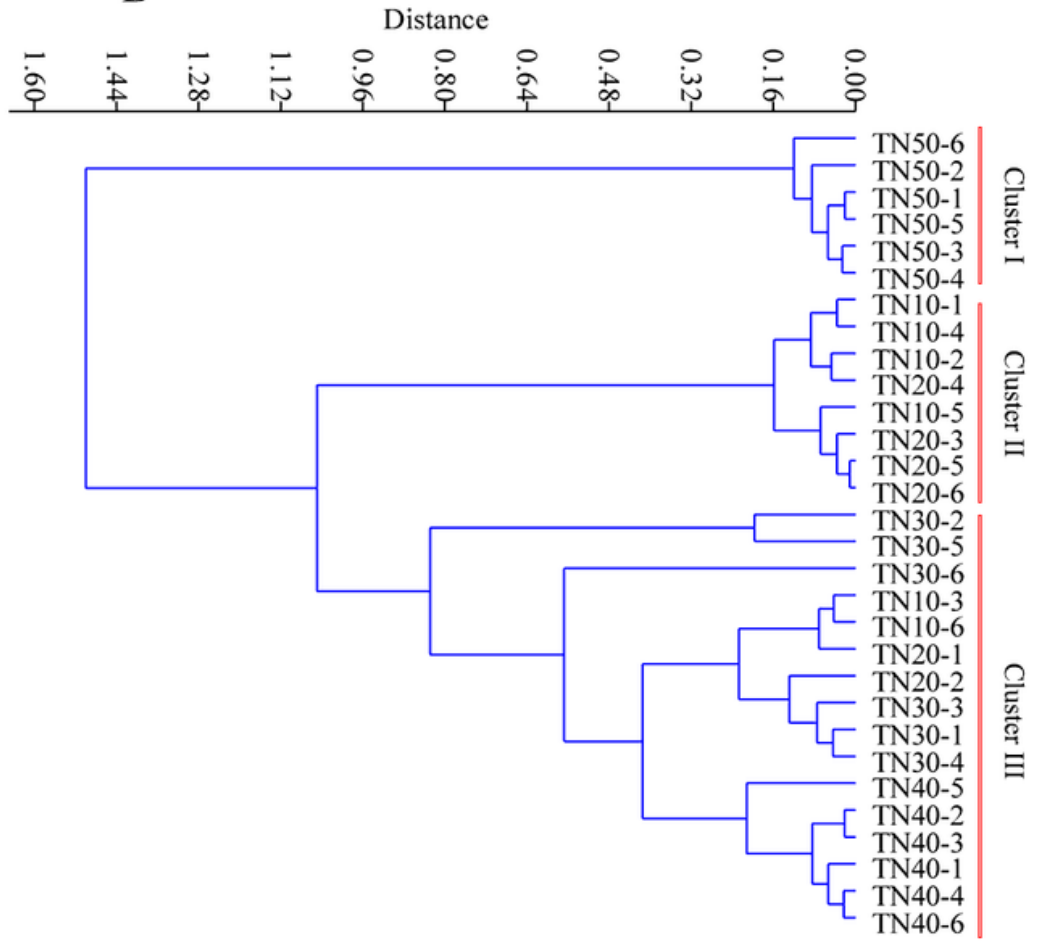

Figure 3

Principal coordinate (A) and hierarchical (B) clustering analyses of nosZ communities at OTU level. 


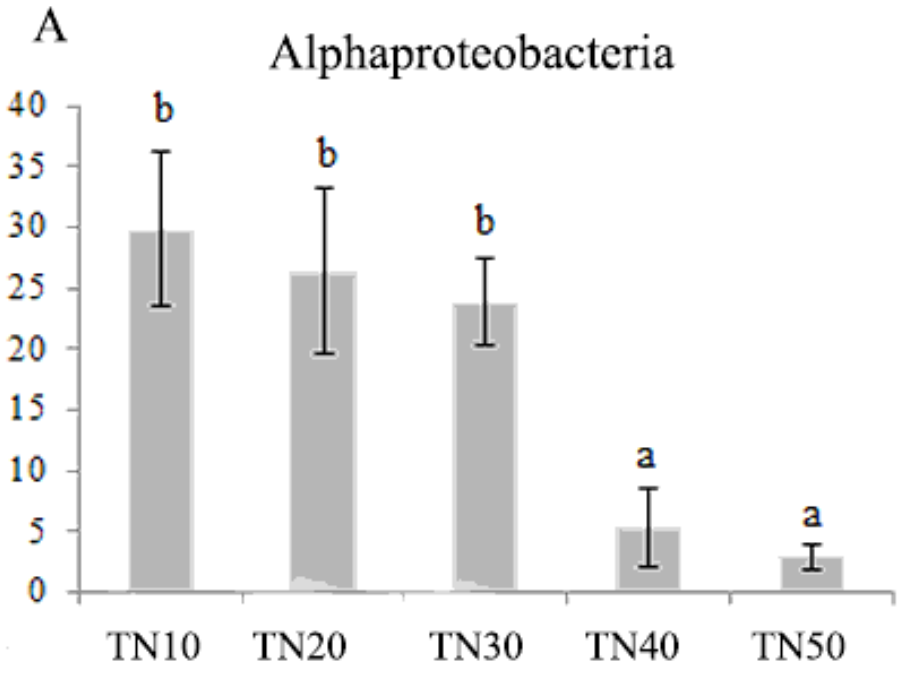

B Betaproteobacteria
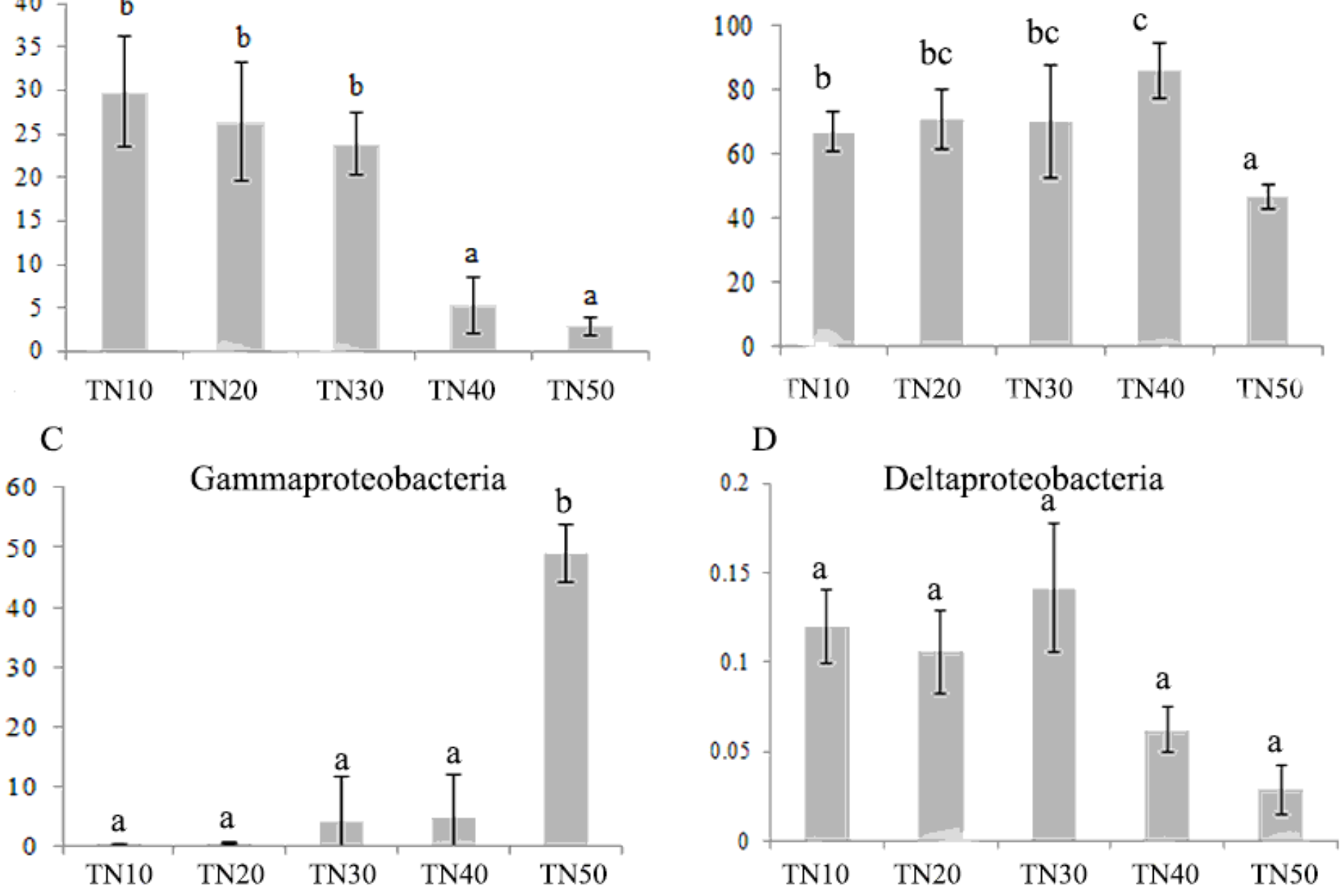

\section{Figure 4}

Relative average abundances of the four most abundant classes for the different groups. Error bars indicate the standard deviation of relative abundance between three replicate samples. 

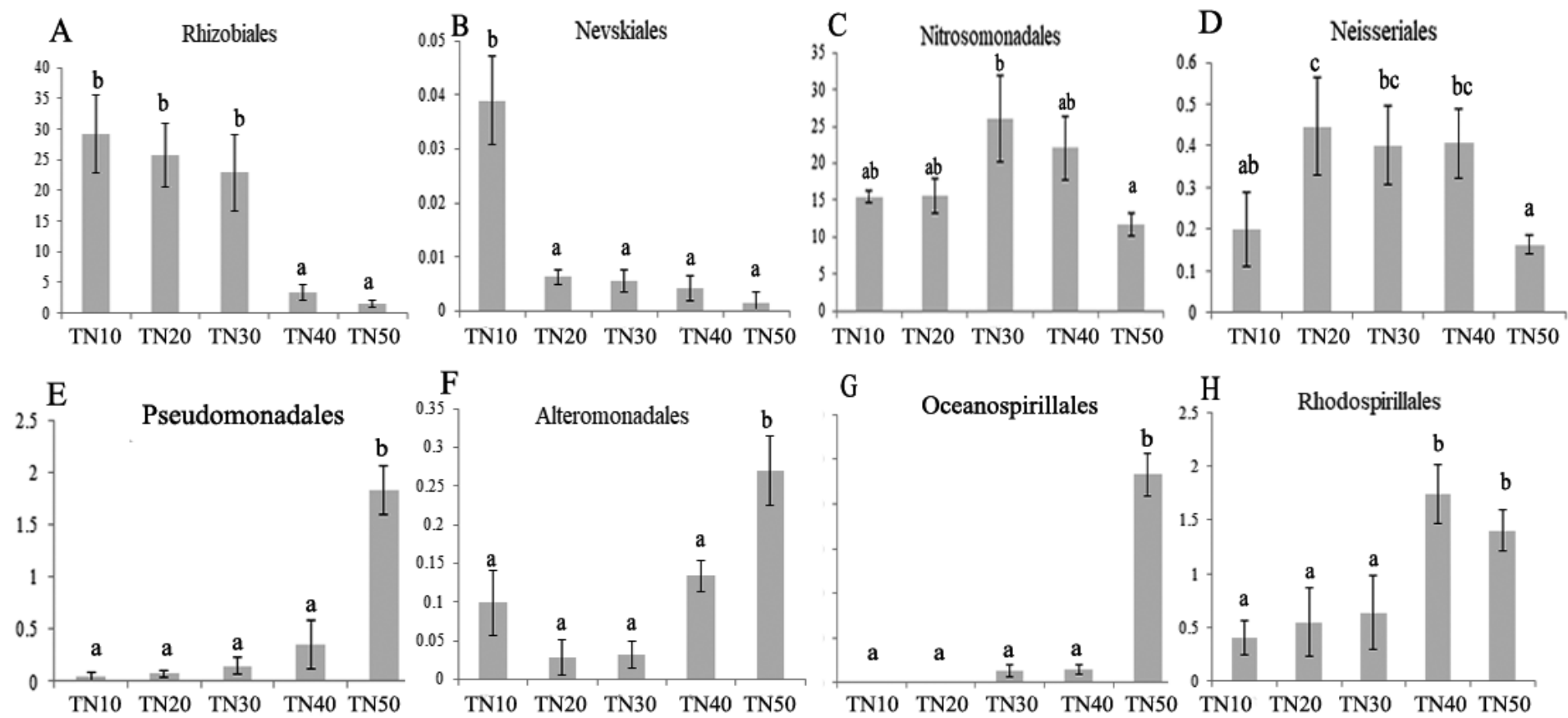

\section{Figure 5}

Relative average abundances of the four most abundant orders in the different groups. Error bars indicate the standard deviation of relative abundance between three replicate samples. 
Tree scale: $0.1 \longmapsto$

Colored ranges

$\square$ Betaproteobacteria

Gammaproteobacteria

Alphaproteobacteria

The relative abundance
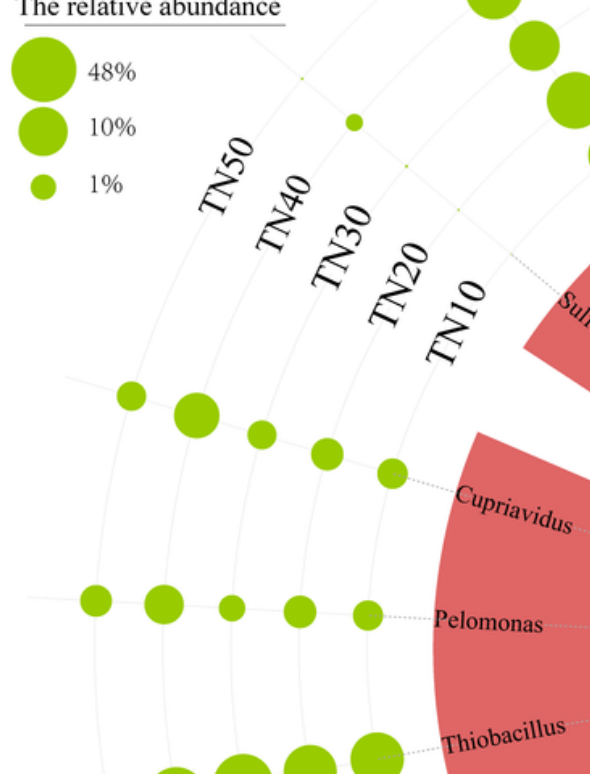

00

\section{Figure 6}

Statistically different denitrifying genera among the five groups. Colored circles represent the relative abundance of each genus. Taxonomic dendrogram shows the inferred evolutionary relationship of the enriched microbiota of each sample. Total relative abundances of all genera and significant effects across $\mathrm{N}$ levels are listed in Table S2.

\section{Supplementary Files}


This is a list of supplementary files associated with this preprint. Click to download.

- FigureS1.tif

- Stables.docx 